Journal of Social Sciences (COES\&RJ-JSS)

ISSN (E): 2305-9249 ISSN (P): 2305-9494

Publisher: Centre of Excellence for Scientific \& Research Journalism, COES\&RJ LLC

Online Publication Date: $1^{\text {st }}$ July 2017

Online Issue: Volume 6, Number 3, July 2017

https://doi.org/10.25255/jss.2017.6.3.643.655

\title{
Transformational Leadership of a Madrasah Aliyah Headmaster (Case study on Madrasah Aliyah Negeri2 Tulungagung)
}

\author{
Soim, Bambang Budi Wiyono, Ali Imron, Imron Arifin
}

State University of Malang, Jalan Semarang 4, East Java, Indonesia

\begin{abstract}
:
This research is on the transformational leadership that was able to make change and make followers of said leadership become more sensitive to work results and values, activating in a higher level, and making followers disregard individual interests for the collective interests of the organization. The purpose of this research is to describe and find substantive theories about the headmaster in designing the vision and missions of the madrasah as well as the development of achieving the goals of the madrasah in Madrasah Aliyah Negeri (MAN) 2 Tulungagung.The method of this study that is used is by using a qualitative approach with a single case wherein it discusses about the transformational leadership of the headmaster and the design of this study is as a case study focused on specific selected cases. The results of this study was that the headmaster was able to realize the vision and missions and the objective of the madrasah in a positive fashion, among them (1) The headmaster of the madrasah had shown remarkable ability in understanding the vision and the missions of the madrasah (2) The vision of MAN 2 Tulungagung that includes efforts to improve the quality of education (3) Realistic and rational vision in the madrasah which he led (4) The achievement of the vision became the duty of all of the components present in the madrasah (5) Designing the collective plan and objectives of the madrasah (6) Studying and improving the school's strategic programs (7) Building good teamwork, and (8) Evaluation being designed based on designed plans.
\end{abstract}

\section{Keywords:}

leadership, transformational, madrasah headmaster

\section{Citation:}

Soim; Wiyono, Bambang Budi; Imron, Ali; Arifin, Imron (2017); Transformational Leadershipof a Madrasah Aliyah Headmaster (Case study on Madrasah Aliyah Negeri2 Tulungagung); Journal of Social Sciences (COES\&RJ-JSS), Vol.6, No.3, pp:643-655; https://doi.org/10.25255/jss.2017.6.3.643.655. 


\section{INTRODUCTION}

A leader is a person who is able to make plans for programs, coordinating, moving, evaluating as well as doing testing and leading work to reach an organization's collective goal. The effectiveness of leadership will include the performance and growth of the group or organization the leader is in charge of, the readiness in facing challenges or crises, the satisfaction of the followers towards their leader, the followers' commitment towards the group's goals, the welfare and psychological development of the followers, the increase of the leader's status in the group and advances to higher commanding positions in her organization as well as the demands that the leader faces. (Yukl, 2001:10).

The leadershipof madrasah headmasters in essence relates to the skills, competence and level of influence an individual possesses in developing the institution she leads. Walsh (1999:32) identifies that successful schools are schools where the students can show development and change that is significant, apart from whether their academic achievements are in high standards or not. The importance of a leader is in developing educational institutions and organizations by moving and motivating her members in reaching an organization's goal in a collective manner.

The success of schools is determined by whether or not the headmaster is a person who determines the focus and atmosphere of the school, in other words, a successful school is a school that possess a leader who is successful (effective leaders). Leaders of a school can be described as someone who has high hopes to the subordinates, staff and the students, in a way as such that the leader knows much about their duties and who determines the atmosphere of the school (Wahjosumidjo, 1995: 3).

Transformational leaders who are effective are leaders who see themselves as agents of change, who are cautious in taking risks, sensitive to the needs of the organization, always open to learning from experience, has a vision and missions that are clear as well as having cognitive competence (yulk, 1998: 304-307).

Transformational leadership is not only defined influencing followers to reach a designated goal, instead it has to do more with wanting to change the behavior and basic values of followers through utilization and the creation of a culture. The experience of utilization of the followers will increase the self-belief and determination to change even if they themselves will be impacted by that change (Gibson dkk, 1996:86).

Transformational leaders are important because they are able to make their followers become more sensitive towards the values and results of work, activating them to a higher level, and thus making them disregard personal interests in favor of the interests of the collective organization. Such influence positions the followers to feel a sense of trust and respect towards the leader as well as being motivated to improve and change, the transformational impact is achieved by using charisma, inspirational leadership, individualized attention, as well as intellectual stimulation.

One of the main characteristics of transformationalleaders is to have the ability too act as an agent of change in an organization, thus she has to be able to create relevant strategies of development in the organization. Based on suchleadershipfunctions, the leadershipof headmasters have to be able to transform the environmental change to manifest a school 
environment that is conductive through the forming of a workplace culture that has high quality in the process of conducting education.

On the issue of leadership theories, researchers have suggested the theories below:

a. TransformationalLeader

Transformationalleaderis a leader who always shows the process of building commitment towards an organizational aim and gives trust in her followers to reach said aims. A few transformational leadership theories also study how leaders change and build an organization's culture to be more consistent in reaching organizational aims.

This early concept on leadership was formalized by Burn (1978) who defined Transformational Leadership as a process that exists in a leader and her followers elevating each other to a higher level of morality and motivation. Such leaders try to instigate a sense of consciousness to her leaders to proclaim higher dreams and moral values.

Bass (1995 in Raihani,2010:24) defined a transformationalleader as an agent of change who acts as a catalyst who gives roles in changing the system to a better path by having a role in improving existing human resources. She tries to create a reactionary force that results in the spirit and quick work ethic, always appears and as the pioneer in bringing change.

Basic values that are most important and are thought of highly by leaders are everything and can be made into a reference for the basic values of the organization that is highly thought of by staff in realizing the organization's vision.

Bass (1995) provides a transformationalmodel as such:

1.1

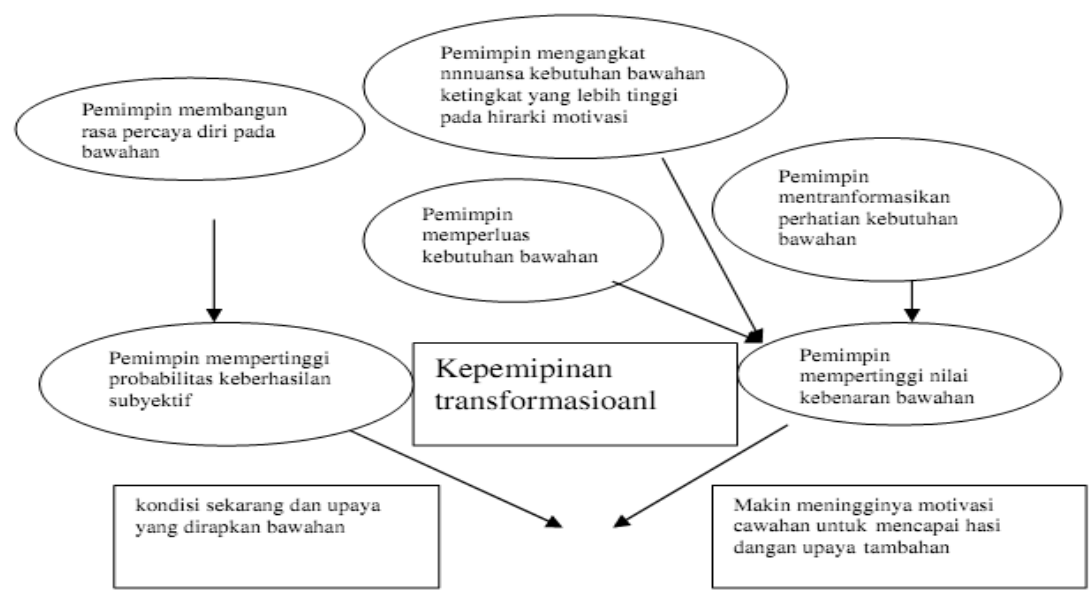

Bawahan mempersembahkan kinerja melebihi apa ynag 


\subsection{Gambar 2.1 Bass' Transformational Model (Source: Bass and Avioalla, adopted} by Khospsoh, 2006)

TransformationalLeadershipis something that is different from charismatic leadership in various aspects. According to Bass (1985:31), charisma is the most important part in transformational leadership, but that charisma in and of itself is not enough for transformational processes. Transformational leaders influence followers by instigating strong emotions and identification to that leader, but they have to also transform followers by acting as a teacher or mentor, which is not the case in charismatic leaders.

b. Transactional Leadership

Transactional leadership is a kind of leadership that focuses on duties bore by subordinates. A leader is someone who designs works as well as its mechanisms and staff are people who do the jobs according to their abilities and expertise.

As depicted in chart 2.2. below:

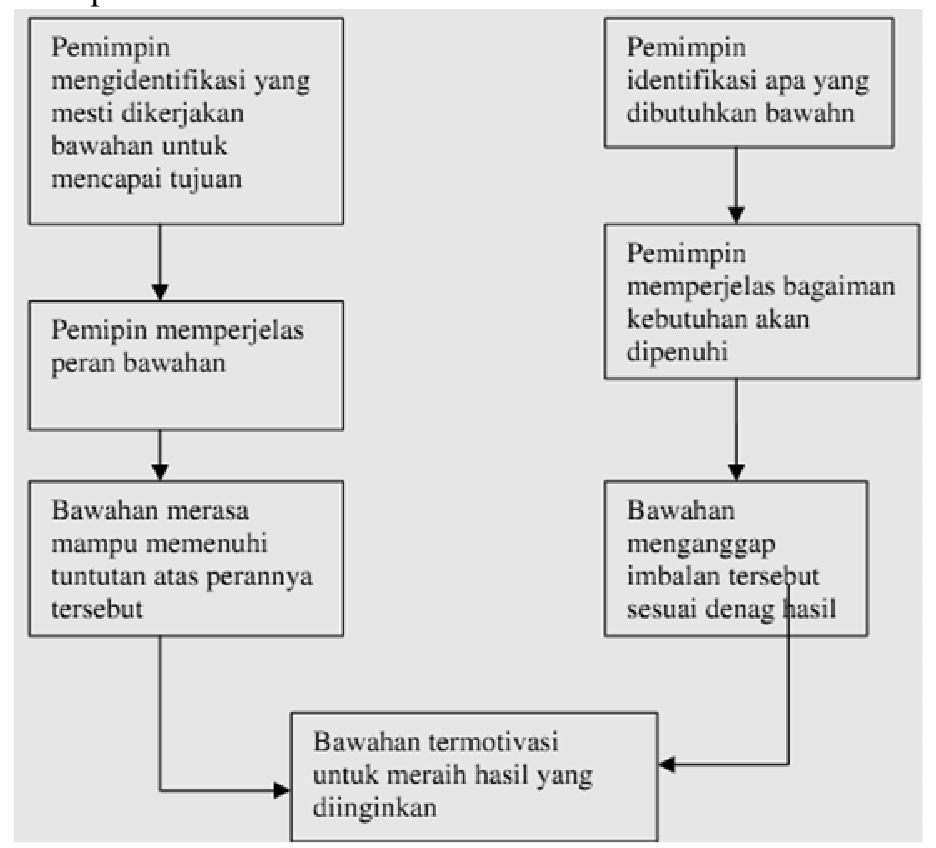

1.3 Picture: Transactional Leadership (Source: Hoover:1991 and Leitwood (1992, )

Transactional leadership focuses more on the role as a manager as transactional leaders are very involved in the procedural and managerial aspects which are more methodological and physical. Transactional leadership is best suited for staff who are novices and intensive jobs aren't based on self-actualization, thus this leadership is faced with people who want to fulfil basic needs.

c. Visionary Leadership

Strong leadership affects the performance of the organization, thus it is reasonable that the crippling of education is caused, among other things, by the performance of leaders who cannot adapt to change and also cannot make education that is not adaptive to change. 
Tilaar states that one of the causes for the crippling of the education sector is the lack of strategic vision that places education as a leading sector.

Leadership that is relevant for the improvement for the qualityof education is visionary leadership; leadership wherein the main job is focused on imagining the future that is full of challenges, thus being an agent of change who is capable, and becomes the determiner of the direction of the organization who understands priority, becomes a professional trainer, as well as guiding personnel to a direction that is hoped.

Visionary leaders will show quality leadership. The characteristics of visionary leaders are as follows; having personal integrity, having enthusiasm in the development of the institution they lead, developing warmth, culture and climate in organizations, stern and fair in institutional policy making. Visionary leaders are also marked by their ability to make clear plans as such that in their vision's design, the goals that will be aspired to in the development of the institutions they lead will be outlined clearly.

The steps of a visionary leader in doing jobs and leadership duties is to create, maintain, develop, and actualize as well as refresh her vision so that it can respond swiftly and accurately to issues and expectations that an organization faces.

d. Cultural Leadership

Cultural leadershipis tied strongly to the culture of an organization. This leadership model compares cultural change and leadership that maintains culture. The conditions and abilities of such leaders create an impression about competence, articulating ideology, communicating strong foundations and high hopes as well as trust towards their followers, acting as acting models and aside from that also motivating the commitment of followers towards the goals and strategy of the organization.

Leaders who maintain culture assert values and tradition that applies and is fit for long term success of an organization, and only makes slight changes in that strategy. On the other hand, leaders who do cultural innovation suggest an ideology with new values to face a serious crisis.

The success of an institution in running their plans and organizational programs need to be supported by creative leaders who are able to increase the participation of the available human resources. The role of a headmaster as a leader requires her to be able to manage the functions of leadership which includes;planning, actuating, controlling, coordinating and evaluating.

Experts have given much evidence from their research on the effect of leadership on the actions of their followers, among them:

1. Leadership is an art that affects other people, leadership is a process in which someone influences their subordinates to act in line with what is hoped. The core of leadership is the technique to influence to reach a collective goal.

2. Leadershipis the usage of influence. Leadership indirectly states that there is an influence that changes the actions of people. Tead comments that the will to voice their opinion is the leaders' ability to influence people to work together in reaching a designated collective goal. This is not dissimilar to Stodgil's view that leadership 
is a process (action) affecting the activity of organized groups in efforts to identify an objective and reach it.

3. Leadershipis a tool to reach a goal, as Cowly states, leaders are individuals who have programs/plans and together with the members of the group work towards reaching that goal with a precise method.

Leadership has a process that appears in each individual, each of tou are leaders who will be asked about your leadership: Meaning: Ibn Umar States : I have heard Rasululloh SAW. Say : You all are leaders and you all will be asked about your leadership, leaders will be asked about things about the people they lead... (HR. Bukhari Muslim).

The core of leadership is among other things the ability of someone in influencing others to reach a positive collective goal, and there are elements of a person who leads, who are led, the existence of organizations and the existence of goals that are collectively aspired to reach.

The headmaster of Madrasah Aliyah Negeri 2 Tulungagung, Dra.Hj Miftachurohmah, M.Ag is a person who is idealistic, highly motivated, energetic and intellectual, proven by his discipline that has to be done by teachers, staff, and students alike. He possesses 3 principles of discipline that can motivate: (1) discipline in time, (2) discipline in learning, and (3) discipline in administration, known from the results of the observations of field researchers that the headmaster in improving with strong professionalism and making the headmaster of the madrasah possess transformational leadership, he encourages all of his citizens to work together to reach the goal of the madrasah. The headmaster of MAN 2 Tulungagung always tries to improve the quality of education through programs that are already stated in the strategic plan of the madrasah. In terms of discipline, the headmaster of MAN 2 Tulungagung instilled behaviors of time discipline to all of the citizens of the madrasah, giving motivation to the teachers, staff and students, creating a working environment that is comfortable, utilizing teachers to make the programs of the madrasah a success and realize a creative learning process such as the administering of learning outside of the classroom (back to nature) as well as giving creative ways to create an interesting learning process. This is proven with the academic and non-academic achievements that have enjoyed a rise from year to year including the increase in number of students every enrollment period and students often winning many competitions whether it be local, regional or even national.

The goal of this study is to describe and find substantive theories about the headmaster of the madrasah in designing the cision and missions of the madrasah as well as the development of the reaching of the goals of Madrasah Aliyah Negeri (MAN) 2 Tulungagung.

\section{A. STUDY METHODOLOGY}

This study uses the case study approach. Robert Yin (1996) states that a case studyis an empirical inquiry that investigates phenomena and real life contexts, which in this case is the transformational leadership of the headmaster of madrasah aliyah Negeri 2 Tulungagung wherein the boundaries between the phenomena and the context is not clear and where evidential sources are used. Thus, this case study hopes to understand the living world and behavior of humans whether it be thought patterns, certain rationales, ethics or cultural values as an effort of understanding (Faisal, 2001:2). 
The case study that is done is a holistic singular case study. The researchers only focuses on one case, which is the issue of transformational leadership of a madrasah headmaster. The researchers have flexibility in the acquiring of data and are not restrained to only one activity.Case studies can also be used in any social issue, in this research location, the researchers deemed it appropriate to use a case study, as they can directly see what has occurred and can correlate it with existing theories and whether the phenomenon is in line with the theories or not.

The design of this study is using a focusedcase studythat is centered on specific cases that have been designated. The process of this study starts with a wide exploration, then continued by the gathering of data that have been selected and focused and in the end those data are analyzed so as though to get a comprehensive conclusion on the transformational leadership of the headmaster of madrasah aliyah Negeri 2 Tulungagung

The sources of data in this study is in the form of human resources including key informants, including the headmaster of madrasah Aliyah Negeri 2 Tulungagung and to complete the data these human sources will also include the vice headmasters, a number of teachers and staff in MAN 2 Tulungagung. Non-human sources include documents and written notes relating to facts in the study, such as documents, publications, archives, and so on (Bogdan \& tailor: 1993). The technique of data collection in this study is by using three approaches, which are: (a) participant observation, (b) in depth interview and (c) documentation..

\section{B. RESULTS AND DISCUSSION}

From the results of interviews with the headmaster, the teachers, the madrasah committee and students, it is known that they are fully aware that vision is an important thing in the running of the madrasah. They are of the opinion that this vision must be realized in sn action and high commitment among them. Without this commitment and real action, then such vision will not be realized, resulting in efforts to increase the quality of education in the madrasah will experience setbacks.

1. The headmaster shows good understanding of the vision and missions of the madrasah. The headmaster stated that in essence the fulfilment of the madrasah vision is not only the duty of the headmaster, but also the duty of all the components in the madrasah. They have to realize that their existence in the madrasah have to actually give real contributions in the education process in the madrasah and they have to be ready in helping the headmaster in duties, specifically in the realization of the goals and vision of the madrasah which have been collectively designated.

The vision of MAN 2 Tulungagung is "MuliaTerbentuknnya peserta didik MAN 2 Tulungagung yang Cerdik, Dedikatif, Inovatif, Kompetitif, Berjiwa Islami dan Berbudaya Lingkungan Sehat Cerdik Bersemi dan Berbudaya Lingkungan Sehat"; "The creation of MAN 2 Tullungagung students who are clever, dedicated, innovative, competitive, has an Islamic soul and have a culture of healthy, clever blossoming environment and have a healthy environmental culture".

There also exists indicators for the vision including having systems and facilities in sending information, having professional human resources at the madrasah, having students who are exceptional, the existence of the behavior of obeying religious teachings, 
as well as obeying the rules of the madrasah, etiquette, and the existence of quality education.

The results of Fauzudin's (2011:277) research suggests that the goal of leaders show the target or direction to which school/madrasah organizations will head to, and goals can be differentiated into two types; short term goals and long term goals. Both are reflected in the planning system. The vision and missions are stated substantively, whilst goals are designed quantitatively, and accomplishing goals requires a development strategy that considers the applicable values.

In relation to the madrasah vision, it is seen clearly that the madrasah wants to manifest the process of education and teaching that is excellent thus being highly competitive and in the end the graduates of this madrasah are able to compete in the global era but put forward spiritual values and the culture of the people.

2. The vision of MAN 2 Tulungagung includes the effort to increase the quality of education in the madrasah with the end goal of increasing the quality of madrasah graduates.

MAN 2 Tulungagung reached shimmering academic achievements and the headmaster also has a dream that the madrasah becomes an excellent madrasah in terms of nonacademic achievements. Madrasahs that become idols for SMP/MTs graduates are madrasahs that aside from having academic achievements also have non-academic achievements. This era of globalization demands madrasahs to be able to face the challenges of the development of science that has sped up and become complex. For that, the mastering of science and technology is needed. In line with this condition, the headmaster wishes that all the civics of the madrasah whom he leads be able to master information and communication technology as well as be able to use English well.

3. The headmaster has done maximum effort into making a vision that's realistic and rational to the madrasah which he leads.

Relating to the effort to form a human identity that relies on her religion as well as being based on the identity of the nation, the headmaster of the madrasah has a dream of wanting to realize a religious and cultural madrasah which also means a madrasah with a religious nuance and highly values the cultural values that exist in the people. This is caused by the condition that currently, SMA/MA aged students have almost lost their identity. Cultural values have almost been eroded in their daily life, as well as spiritual values. This is very disconcerting for the development of the children's soul. Children will grow to be intelligent people yet not have strong character or faith. Madrasahs have to be able to build a child's soul that has excellence in terms of academic as well as non-academic achievements and strong spiritual strength as well as still being based on the identity of the nation. Because of that, the process of learning that is done in this madrasah is not done only to reach for academic and non-academic achievements as well as intellectual and emotional intellect, but also the planting of spiritual values. Thus, it will impact the personal shaping of students who have resistence in facing the different challenges in life.

Smith \& Andrews (1989) in Sobri (2009:328) explains that as a communicator, the headmaster can do six activities, including: demonstrating ability in evaluating and relating with other people, speak and write clearly, using skills and strategy in managing 
conflict, fascilitating groups in choosing problems through problem solving techniques, demonstrating ability in using a plethora of group process skils in interactions with staff, parents, and students, as well as demonstrating skills in working as a part of a team.

The vision of theleadershipof the headmaster of MAN 2 Tulungagung is directed to manifest the madrasah's vision, that is to become a madrasah that's excellent in the administration of education and learning to produce competent and competitive graduates, mastering science and technology in the global world based on faith. The vision of theleadershipof the headmaster is to realize a madrasah that has high achievements in both academic and non-academic fields, high discipline, having the trust and support of the people, that is religious and are able to build the cultural character of the people as well as the mastery of information technology.

4. The achievent of the madrasah's vision is not only the duty of the headmaster, but also the duty of all the components within the madrasah.

A madrasah can be called as having quality if the school's achievements, specifically the achievements of the students are high in academic achievements including grade scores that fulfil standards, have values of truth, faith, politeness, and are able to appreciate cultural values and have high responsibility and ability that is manifested in the form on skills according to the knowledge that they receive in school. In the planning of the vision, missions and the goals of the school, the researchers attended the meeting that was held by the headmaster in the teacher's room. The researchers listened to the explanations given by yhe headmaster but did not overly suggest things on the vision, mission, and goals of the school, which is because the researchers did not possess adequate understanding of administrational planning and administration in general. Because of that, to develop the school to a better direction, the researchers agreed to the things said by the headmaster, which is also to support development to a better direction without negatively impacting any one side.

Good coordination between the headmaster and all of the teachers is hoped so that there exists no informational discrepancies, whether it be from the headmasters to everyone, so that there would not exist pushing each other in giving information to the parents.Dealing is the best way in designing a plan so that in the future it will run smoothly.

The activity was done at the start of the new school year, where the entirety of the teachers hold a meeting with parents. In the meeting, the plans of the school are explained, specifically ones relating to the original goal of the creation of the vision, missions, as well as the goals of the school. Of course, the school hopes that the parents are able to participate in supervising and overseeing their children's develppment in their studies. With the existence of this meeting, the researchers hope that the parents know about the purpose od the school as well as being able to participate to give advice where there is an incorrect goal, but the researchers were pleased because the parents were able to support the goals that were designed and they were willing to cooperate with the school to pay attention to the development and improvement of their children's studies. 
5. The headmaster and the board of teachers design a plan and goals of the madrasah to keep developing and innovating.

In the strategic goal designing process, every institution first designates the vision, missions, objectives, and aims that is desired. For the goals of the school to run smoothly, the headmaster explains that: in the strategic goal design process, of course, the basic thing that have to be early guides is the stratefic plan that has been designed first. With the managerial ability that I have during years of teachinf and then becoming a headmaster, I designed it in such a way the strategic plan for this school, then I coordinate with the teachers in the meeting. In the process of creating the school goals we based it on the planned activities. Of course ranging on the 8 standards of school education, including the assembly of a school administration, adequate facilities and utilities, the assembly of RKAS, good coordination between teachers, the assembly of RAPBS, the religious activities in the school being run well, excetra. Of course schools also see and observe the internal or external environment so that the school's objectives are in line with the environment outside the school. That has been well received by the citizens of the school, there are a few teachers who reacted to the design off the strategic plan, but there are also some who I met who still feel that they do not yet quite fully understand what the strategic plan is. There are also factors that cause this including the board of teachers not yet understanding the meaning of management in depth, of course age is a factor, as some of the more senior teachers also feel rather confused about such things.

6. The implementation of the headmaster and a few teachers reviewing and developing the strategic program of the school.

MAN 2 Tulungagung always thinks and plans activities that will be done, of course relating with the ability of the school in doing such things. Structured coordination will be able to ease the goal that will be reached. The committee sir has been vert supportive and gives much motication as well as encouragement to us to further support the performance of schools as such that it becomes known in the city of Tulungagung with shimmering achievements. From the results of the interview it is known that the strategic goals will be met if it is designed with maximum effectiveness, but challenges will always exist in every activity that is done, such as the case of funding that has not been adequate to make an activity to develop the school; the creation of a computer laboratory to support education in information technology. Discipline in teaching is sure to impact positively in the output that is desired, support for the professionalism of the teachers must always be done to get quality students.

The achievements above are reached based on the consideration and input from the board of teachers, thus the stratefic plan can be formulated well and in line with the components in the field of education, which will certainly affect the development of the school in the future to reach the school's desired strategic goals. For that, good teamwork will of course produce good performance to reach the collective goals. Activities that canimprove the school and support the effectiveness of the students are widely supported by stakeholders; the people around the school.

7. The headmaster builds teamwork well, goals will be well met through the awareness and responsibility of each person in the given job descriptions. 
The madrasahwill reach the desired hoals with good teamwork, as it will make sure that goals will be well met and of course needed is an awareness and sense of responsibility on every individual's part in the division of duties that has been done. The executor of the plan has a ver strategic position in its implementation, because however ideal the program or plan that will be implemented, if the choice of executor is incorrect, in which she does not have the ability and skills as needed, then all the programs and plans will not be able to meet the desired aims.

In the implementation phase, I and a few teachers reviewed and developed strategic programs for the school, of course related to the standard components of education, including 1) content standards including the formation of work programs, syllabus, 2) process standards including the formulation of RPPs, grading formulation, 3) educator and education standards including the fulfilment of teaching qualifications with S2 qualifications, teacher certification, 4) facilities and infrastructure standards including the fulfilment of a computer laboratory, a library and classrooms,5) grading standards including grading devices based on information technology, 6) management standards including the formulation of annual and 5 year work plans, of course becomes a step-bystep process for the execution of that program so that the results can run at maximum capacity.

In the implementation step, schools need to do reviewing and development so that programs that have been made can be run smoothly. In addition to that, the execution of such programs are not direct, but instead is done in steps according to the program that is easier to be executed first. The organization structure of the school is also very important in the movement of said implementation, because it can be seen that each organizational structure has an arrangement of coordinators that move along school activities.

Every planning of an activity is not separate from the existence of a meeting that is done to socialize the performance that will be done. In that regard there is found a few things based on the results of interviews with the headmaster. Every planned program of course is in line with the capabilities of the school to execute it. Lack of coordination will make a social gap that can break bonds and the appearance of behavior in prioritizing individual interests without caring about other teachers. The awareness of each individual is needed to know as well as observe where she has duties and will always be responsible for a duty that has been given by the leader, in this case the headmaster.

8. Evaluation is done so that the madrasah can know the results and if they are in line with the formulated plan.

Evaluation is needed in knowing just how well a plan has been done, so that the school can know the results that has been acquired and if it is in line with the formulated plan.MAN 2 Tulungagagung, through all available components, always tries its best to get the best result, but of course must still be evaluated in the end of the semester, so that it can be known how well the program has run. For that, evaluation is much needed to evaluate the performance of the school according to the school's strategic plan. By doing an evaluation, it is hoped that programs that have not been done well yet will be repaired. Of course in evaluation, there are steps that are done before it is done, starting from reviewing strategic plans that has been done during one year to the 5-year plan. After that, programs that have not been done will be investigated to know what caused them to fail to 
be done. For example, a program for teachers to attend training, inadequate facilities and infrastructure, caused by the inexistence of financial aid from the department of education, to the determination for strategic programs of the school, have been allocated a date and month for the execution of the designated activities.

Evaluation is much needed to know the results of planned programs because evaluation is the final step in measuring programs. After the evaluation is done, then improvements will be done in the designated program so that it can reach a mark as desired by the school.

The evaluation phase is a very important stage that is needed to know the performance of the strategic planning of the school in the future, with evaluating things that have not be done, improvements so that the plans are not in vain can be done, because with improvements the school will still develop and can compete with other madrasahs.

The abilities above is not apart from the skill of the headmaster of MAN 2Tulungagung who has a technique of self-evaluation. Wiyono (2017:144) gives clear details in which the technique of self-evaluation has proven effective in increasing transformational leadership, teacher's work motivation, and effectiveness of teamwork and the improvement of schools. The self-evaluation model with feedback has a stronger effect than the model without feedback.

The headmaster along with the teachers have exercises and the doing of exams including national and university entrance exams with the aim of making students used to such exams so that they can graduate and be accepted in a quality university. The headmaster along with the teachers have been keeping up efforts to improve achievements in nonacademics in a variety of interest and talent-based activities. This non-academic improvement is done by the school via extracurricular activities. Strategies done by the headmaster to develop the interests, talents and creativity of students is by way of the counseling teachers as well as forming school teams to help students through extracurricular activities and counselling.

\section{CONCLUSION}

In conclusion, from this article about the headmaster in the formulation of the vision and missions of his madrasah as well as developing the achievement to the goals of Madrasah Aliyah Negeri (MAN) 2 Tulungagung, it can be known and understood that the headmaster is making effort in creating a school that is lush, cool beautiful and comfortable that in the end can bring peace and calmness to the citizenry of the school in doing their duties in the school. The headmaster in running his strategy in developing the madrasah effectively has done it by functioning as a leader in decision making, in commanding, in giving consultation, in participating and in delegation in each activity. The headmaster has been able to give a good example of teaching and keeps trying to increase the quality of education that is being done by the teachers. The factor of experience is key in the professionalism of the headmaster, especially in supporting the formation of understanding of the educational workforce to the execution of his job.

The actualization of the achievement of the goals in the vision and missions of the madrasah is as follows: (1) The headmaster has given motivation to the students to develop interests and talents through extracurricular activities, though it seems to have garnered inadequate attention from the students, (2) The headmaster has tried to work 
together with the school committee and parents in an effort to gain financing to complete the facilities and infrastructure in the school. As proof of his seriousness in this regard, he has designated an education fund for this cause (3) The headmaster works together with the school committee and the parents in discussing about the required facilities and infrastructure that is needed to support the education process in the school. (4) The headmaster always coordinates with the school committee and every semester a meeting is held between the school, the school committee and parents discussing the development of the education process in the school and the completeness of the supporting facilities and infrastructure. (5) The headmaster is active and can build mutual relationships. According to him, to achieve the vision and missions of the school in accordance to the new paradigm of education management, there exists a need to utilize the school committee, parents, people and school environment optimally.

The headmaster has shown real effort in developing working relationships between the school with the school committee, parents, and the populace. The headmaster, in managing the school has shown an openness in it. Everything from the creation of work programs, socialization of programs, executing the programs, monitoring them and making the report of the programs has been done together by all the citizenry of the school.

\section{REFERENCES}

Bass, B.M. 1985.Leadership and Performance Beyond Expectations. New York: The Free Press.

Bass,B.M and Avolio B.J. 1994. Improving Organizational Effectiveness Through Transformational Leadership. SAGE USA

Bogdan, Robert C. and Biklen, Sari Knopp. 1998. Qualitative Research for Education: An Introduction to Theory and Methods. New York: Allyn and Bacon, A Viacom Company.

Faisal, Sanapiah, 1996.Penelitian Kualitatif, Dasar-dasar dan Aplikasinya, Malang: Y.A.3

Fauzuddin. 2011. Kepemimpina Transformational Kepala Sekolah Studi Multi Kasus pada Dua SMA Negeridan Satu MA NegeriBerprestasi di Kota Banda Aceh. UMMalang. Disertasi: tidak diterbitkan

Gipson, Ivanche, donnely 1996, Organisasi, Prilaku Organisasi, Jilid 1 Alih Bahasa Nunuk adian., Jakarta: Bina aksara

Raihani, 2010. Leadership Sekolah Transformational.Yogyakarta:LKiS

Sobri. Ahmad Yusuf, 2009. Peran Kepala Sekolah dalam Meningkatkan Kualitas Pembelajaran Studi Multi Situs pada SD Widada,SD Mawar, dan SD Iman Kabupaten Bayuangga. UMMalang. Disertasi: tidak diterbitkan

Walsh,M. 1999. Building a Successful School. London: Kogan Page Wahjosumidjo, 1995: 3)

Wiyono, Bambang Budi 2017. The effect of self-evaluation on the principals' transformational leadership, teachers' work motivation, teamwork effectiveness, and school improvement. International Journal of Leadership in Education-Theory and practice. 27 April 2017

Yukl. Gary, 2001, Leadership in Organizations.Englewood Cliffs. NJ:Prentice Hall. 